\title{
A pilot study of a mobile spirometry service in primary care
}

\section{Rupert Jones*, Margot Whittaker, Karen Hanney, Bryanie Shackell}

Respiratory Research Unit, ITTC Building (N21), Davy Road, Plymouth, PL6 8BX, UK

Received 8 November 2004; accepted 22 December 2004

Summary This evaluation of an inexpensive mobile spirometry service demonstrates how patients with respiratory problems can be diagnosed and referred to appropriate services, with major potential benefits to the patient and the retir service. (c) 2005 General Practice Airways Group Putief ed by Eisevier Ltd. Âlbrist: reserved.

\section{Introduction}

Early diagnosis of chronic obstructive pulmonary disease (COPD) can prevent decline into progressive debilitating respiratory failure [1]. Once diagnosed, treatment strategies (e.g. drug and oxygen therapy, specialist support, pulmonary rehabilitation and smoking cessation [2,3]) can control symptoms, reduce morbidity, and improve quality of life. Patients with severe disease create a burden on the NHS, with frequent GP consultations, high drug costs and hospital admissions $[2,4]$.

COPD is under-diagnosed in primary care $[5,6]$ where spirometry can be performed accurately [7] despite major problems $[8,9]$. These include: access to a spirometer; under-use of spirometry;

\footnotetext{
* Corresponding author. Tel.: +44 1752 764293; fax: +44 1752764259.

E-mail address: rupert.jones@pms.ac.uk (R. Jones).
}

problems interpreting results; and a lack of training, support and expert advice [4].

This study evaluated a structured COPD diagnostic and management service provided by a trained Respiratory Specialist Nurse (RSN) experienced in practice nursing.

\section{Methods}

The following were offered to 14 general practices randomly selected from all practices in Plymouth known to own a spirometer:

- Practice staff education (spirometry, data interpretation, COPD management)

- Spirometry clinics offering bronchodilator and steroid reversibility assessments (BTS $^{2}$ and GOLD $^{3}$ ).

Spirometry results were interpreted by the RSN and a 'respiratory special interest' GP (RJ) who provided diagnoses, management advice 
Table 1 Summary of reasons for declining specialist service.

\begin{tabular}{ll}
\hline $\begin{array}{l}\text { Reasons given for declining } \\
\text { spirometry service }\end{array}$ & Number of practices \\
\hline Already well organised & 3 \\
$\begin{array}{l}\text { Failed to respond to } \\
\text { reminders and calls }\end{array}$ & 3 \\
Time constraints & 1 \\
\hline
\end{tabular}

and individual recommendations for services e.g. smoking cessation, pulmonary rehabilitation, physiotherapy and respiratory specialist nurses, to the practices.

\section{Results}

Of 14 practices approached, seven accepted the service. Table 1 shows the reasons for declining the service.

Only $6 \%$ of patients had normal spirometry, and many new cases of COPD were diagnosed, often at a late stage. Tables 2 and 3 summarise the patient diagnoses and assessment outcomes respectively.

Practices and patients reporied (10iglel levels of satisfaction and w'an ted tie service to corl. tinue. Most nurses were wore conficent peefforming spirometry, although only half were more confident interpreting results. The total cost of the study was approximately $£ 6189$. After deduction of set-up expenses the cost was $£ 107$ per new patient diagnosed with COPD.

\section{Discussion}

Some practices with spirometers lacked a structured approach to COPD management, and lacked
Table 3 Summary of patient assessment outcomes.

\begin{tabular}{ll}
\hline Patient assessment outcome & Number of patients \\
\hline Current cigarette smokers & 22 \\
$\begin{array}{l}\text { Requested information about } \\
\text { disease }\end{array}$ & 65 \\
$\begin{array}{l}\text { Poor inhaler technique } \\
\text { Required referral to Consultant }\end{array}$ & 52 \\
$\begin{array}{l}\text { Required referral for pulmonary } \\
\text { rehabilitation }\end{array}$ & 20 \\
\hline
\end{tabular}

the skills, confidence and time to treat breathless patients appropriately. Despite appropriate services being available, a large number of symptomatic COPD patients lacked any effective care, and had a very poor quality of life [10].

Spirometry is required for the accurate diagnosis and monitoring of COPD. Quality markers for the GMS contract [11] include diagnosis using spirometry (with reversibility testing), regular review, and smoking status/cessation advice. However, despite the consequentincrease in the amount of spirometry taking bact in practices, the benefits to the putien and the health service are quisstionable if the test is not correctly performed and accuralobly in erpeted.

a)ecess to spirometry services varies considerably but problems are common to all regions. In this study, an external nurse-led service was well-received, suggesting that highly trained staff providing a consistent approach may prove beneficial to patients and health professionals alike.

This was a small three-month study of seven practices in Plymouth. It is possible that had the study run for longer, referral patterns may have changed and the consequence of education within the practice may have changed the need for the service. This aspect requires further study.

Table 2 Summary of patient diagnoses.

\begin{tabular}{|c|c|c|c|c|c|c|c|c|}
\hline \multirow[t]{2}{*}{ Diagnosis/Spirometry results } & \multicolumn{7}{|c|}{ Practice number } & \multirow[t]{2}{*}{ No. of patient } \\
\hline & 1 & 2 & 3 & 4 & 5 & 6 & 7 & \\
\hline Normal lung function & & 1 & & & & & 5 & 6 \\
\hline Lung restriction & & & & & & & 5 & 5 \\
\hline Asthma & 1 & 1 & 3 & 3 & 1 & 7 & 3 & 19 \\
\hline Chronic obstructive pulmonary disease & & & & & & & & $(68)$ \\
\hline Mild COPD & 1 & 2 & & 8 & 1 & 4 & 9 & 25 \\
\hline Moderate COPD & & 3 & & 1 & 2 & 2 & 8 & 16 \\
\hline Severe COPD & 1 & 4 & 1 & 4 & 1 & & 16 & 27 \\
\hline Total number of patients & 3 & 11 & 4 & 16 & 5 & 13 & 46 & 98 \\
\hline
\end{tabular}




\section{Conclusions}

This well-received, inexpensive, peripatetic service enabled the diagnosis and treatment of many new cases of COPD.

\section{References}

[1] Fletcher C, Peto R. The natural history of chronic airflow obstruction. BMJ 1977;1:1645-8.

[2] British Thoracic Society. Guidelines for the management of chronic obstructive pulmonary disease. Thorax 1997;52:S1-28.

[3] Pauwels RA, Buist S, Calverley PM, Jenkins CR, Hurd SS. Global strategy for the diagnosis, management, and prevention of chronic obstructive pulmonary disease. NHLBI/WHO Global Initiative for Chronic Obstructive Lung Disease (GOLD) Workshop summary. Am J Respir Crit Care Med 2001;163:1256-76.

[4] Britton M. The burden of COPD in the U.K.: results from the Confronting COPD survey. Respir Med 2003;97(Suppl C):71-9.
[5] Renwick DS, Connolly MJ. Prevalence and treatment of chronic obstructive airways disease in adults over the age of 45. Thorax 1996;51:164-8.

[6] Van Schayck CP, Loozen J, Wagena E, et al. Detecting patients at high risk of developing chronic obstructive airways disease in general practice: a cross sectional case finding study. BMJ 2002:1370-4.

[7] Schermer TR, Jacobs JE, Chavannes NH, et al. Validity of spirometric testing in a general practice population of $\mathrm{pa}$ tients with chronic obstructive pulmonary disease (COPD). Thorax 2003;59:861-6.

[8] Jones RCM, Freegard S, Reeves M, Hanney K, Dobbs F. The role of the practice nurse in the management of COPD. Prim Care Resp J 2001;10:106-8.

[9] Eaton T, Withy S, Garrett J, et al. Spirometry in primary care practice. Chest 1999;116:416-23.

[10] Jones PW. Health status measurement in chronic obstructive pulmonary disease. Thorax 2001;56:8807.

[11] Department of Health. Investing in General Practice, The New General Medical Services Contract. 2003. www.doh.gov.uk/gmscontract.

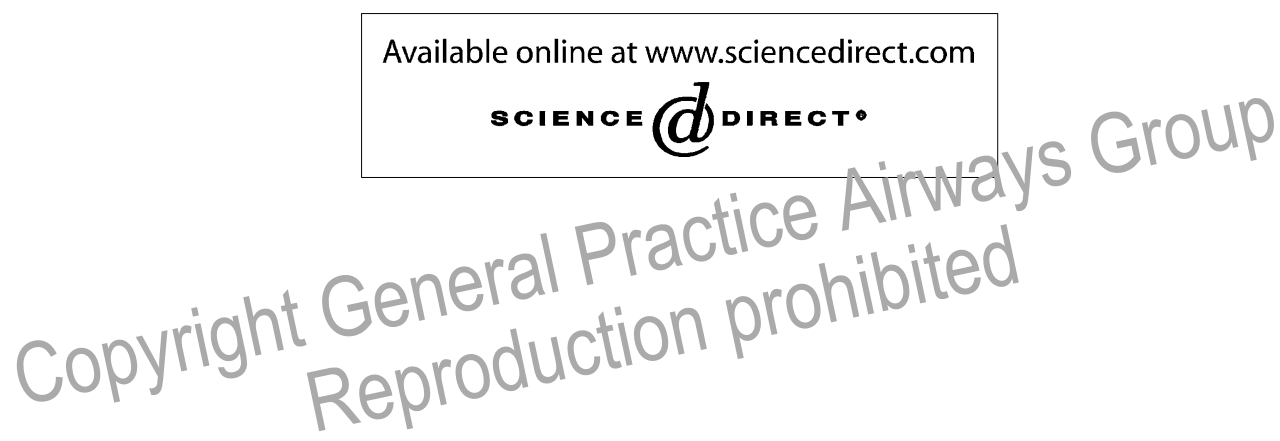

Available online at http://www.thepcrj.com 